\title{
Do NIMBY ao NOPE
}

Ricardo Abramovay

E OI EM 1976, quando as autoridades ambientais da Califórnia recusaram a permissão para que a Dow Chemical iniciasse as obras de um investimento petroquímico de U\$ 500 milhões, ao longo do Rio Sacramento, que a expressão "Not In My Backyard" (NIMBY) começou a ser empregada nos Estados Unidos. A nuvem tóxica sobre Seveso, na Itália, no mesmo ano, contribuiu para alastrar o uso do termo: em ambos os casos, naquela época, as reações das empresas - da mesma forma que na tragédia de Minamata, nos anos 1950, no Japão - eram completamente defensivas, e os órgãos ambientais exerciam, antes de tudo, uma função basicamente repressora e que colocava em lados antagônicos movimentos sociais e grandes companhias privadas. A política ambiental nasce, nos anos 1970, como um fenômeno basicamente regulatório e provoca uma tensão permanente com o mundo empresarial que enxerga tanto nos órgãos públicos como, sobretudo, nos militantes a mistura nefasta de tentação totalitária sobre a vida econômica com nostalgia contrária à própria noção de progresso.

Quem acompanhou o noticiário referente ao Painel Intergovernamental de Mudanças Climáticas, realizado em janeiro de 2007 em Paris, não teve dificuldade em perceber o quanto o ambiente cultural, político e institucional com relação ao tema mudou. No lugar do NIMBY, o termo que sintetiza as aspirações atuais é NOPE: "Not On The Planet Earth". A mudança institucional mais importante na transição do NIMBY ao NOPE, nos últimos trinta anos - e aquela em que se podem talvez depositar as maiores esperanças na solução dos problemas ambientais globais -, refere-se a um conjunto significativo de transformações no mundo empresarial e na maneira como as organizações econômicas contemporâneas concebem sua relação com o meio ambiente. Hoje não há empresa de certo porte em que o tema da responsabilidade ambiental esteja ausente. Mais que isso: de limite a seu crescimento e a seus lucros, o meio ambiente vai-se tornando cada vez mais um elemento estratégico decisivo na própria capacidade de a empresa estabelecer padrões de relacionamento com seus fornecedores, seus clientes e a opinião pública em geral.

É claro que essa transição não é nem poderia ser linear, e o risco de que sob a "responsabilidade ambiental" escondam-se práticas predatórias é tanto maior quanto menor a força do movimento ambientalista e a própria valorização do meio ambiente diante de objetivos sociais e econômicos que conduzem a sua deterioração. Mas o esforço do Instituto Socioambiental em negociar diretamente com fazendeiros na área do Xingu, a presença de dirigentes da ONG Saúde e Alegria em Davos são exemplos que mostram uma permeabilidade da organização das empresas à pressão social - particularmente em temas que tocam o meio ambiente - que talvez seja um dos mais importantes fenômenos contemporâneos.

O livro de Jacques Marcovitch pode ser considerado uma espécie de introdução ao ambientalismo corporativo de nosso tempo. Mas não se trata de um tema de especialistas ou de uma aborda- 


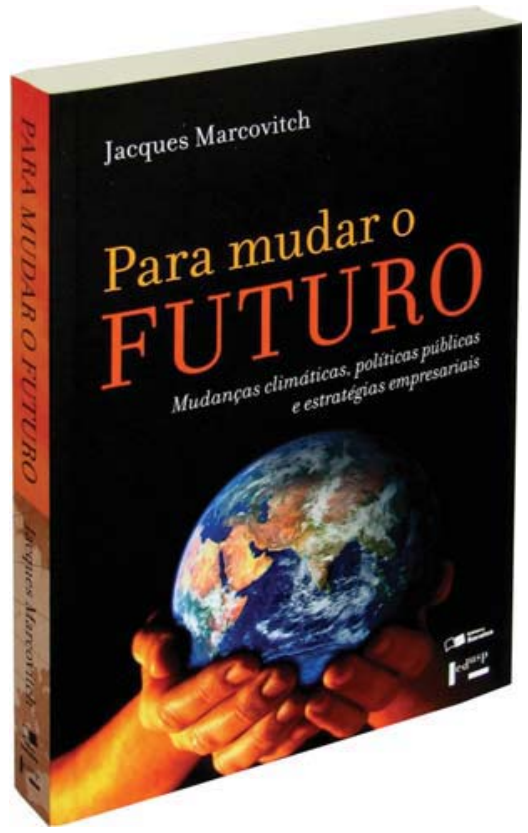

MARCOVITCH, J. Para mudar o futuro. Mudanças climáticas, políticas públicas e estratégias empresariais. São Paulo: Edusp, Saraiva, 2006.

gem que interesse apenas aos responsáveis pela gestão empresarial. A experiência de Jacques Marcovitch na gestão da pesquisa científica (como reitor da USP), na administração empresarial (por suas responsabilidades no complexo energético de São Paulo) e, mais recentemente, na pesquisa em organizações internacionais sobre a mudança climática resulta num livro-manifesto com duas características básicas. Em primeiro lugar, o livro é uma denúncia e um alerta cujas principais informações são totalmente corroboradas pela divulgação científica mais recente, sobretudo no que se refere ao aquecimento global. Mais importante, porém, que a denúncia, é que se trata de uma obra escrita "Para mudar o futuro", como diz seu título.

O livro sintetiza um conjunto variado de iniciativas científicas, da sociedade ci- vil e empresariais que representam o que há de mais avançado hoje na transição do NIMBY ao NOPE e na transição do ambientalismo puramente regulatório àquele que procura incorporar ao próprio funcionamento dos mercados e das estratégias empresariais a preservação e a exploração sustentável dos recursos naturais. Dos combustíveis do século XXI às florestas públicas sob responsabilidade de gestão privada, Jacques Marcovitch oferece um mosaico de iniciativas concretas voltadas a resolver o grande problema do nosso tempo, a compatibilização entre o desafio do desenvolvimento e a urgência da conservação e da regeneração dos ecossistemas de que dependemos.

Talvez a maior prova de que o ambientalismo faz parte das próprias estratégias empresariais contemporâneas esteja nas entrevistas que Jacques Marcovitch reproduz, realizadas especialmente para o livro, com oito organizações corporativas atuando no Brasil e cujas inovações na maneira de incorporar os temas ambientais a seu funcionamento são colocadas em destaque. Em seguida, o autor entrevista dez dos mais importantes especialistas brasileiros em temas ambientais, num rico painel das diferentes posições que hoje dominam o debate nacional.

A passagem do NIMBY ao NOPE não é a entrega dos temas ambientais da regulação pública ao controle privado. $\mathrm{O}$ papel do Estado é decisivo, mas é óbvio - como bem mostra a atitude inteligente do Brasil e de alguns outros países em desenvolvimento com as Florestas $\mathrm{Na}$ cionais - que sem a participação ativa da sociedade civil a legislação ambiental dificilmente tem chances de sair do papel. A grande novidade do nosso tempo - e 
aqui reside um dos temas mais promissores nos estudos ambientais contemporâneos - é que o próprio setor privado e os próprios mercados incorporam, de forma crescente, valores a suas marcas e à gestão dos recursos que detêm. Empresas, marcas, mercados não são realidades que se encontram fora do mundo social $\mathrm{e}$ às quais forças organizadas precisam permanentemente opor-se, de fora para dentro, sob a forma de controle e de vigilância. Ao contrário, o mundo empresarial está imerso no mundo social e daí vem uma das fontes mais importantes para sua própria capacidade de inovação e uma das mais robustas esperanças de que é possível "mudar o futuro".

Ricardo Abramovay é professor titular do Departamento de Economia da FEA, do Programa de Ciência Ambiental da USP e pesquisador do CNPq.

@ - abramov@usp.br

www.econ.fea.usp.br/abramovay/

\section{Errata}

No texto de apresentação do CD "Sons do grande sertão", publicado na edição anterior de Estudos Avançados (número 58, p. 83-87), não foi informado ao leitor que a música Canção de Suruiz, reproduzida na faixa de número 2, foi a composta pelo músico e compositor Luiz Henrique Xavier, a partir da melodia folclórica cantada e adaptada por Antonio Candido, para o CD distribuído em 1977, da coleção "Ler e Ouvir, 1 - Guimarães Rosa, 7 Episódios de Grande sertão: veredas", nas vozes de Antonio Candido, Davi Arrigucci Jr. e José Mindlin”, dirigido por Marly da Cunha Bezerra e Maria de Lourdes Nogueira Porto. 